\title{
Ecotourism and Environmental Education: connecting different concepts
}

\section{Ecoturismo e Educação Ambiental: conectando diferentes conceitos}

\author{
Thaís Varandas de Azeredo, André Scarambone Zaú
}

\begin{abstract}
Environmental Education bases the learning process in the contact with the environment in everyday life. When this relation is developed alongside with emotions, it becomes more than just an informative education. If developed within a critic vision, this process may act in a behavioral change that could help nature conservation. This form of education may happen in natural areas through guided walks, interpretative trail, informative signs and others. Considering all the concepts in this process it's important to show nature as something interesting and, as a consequence, to reveal the need of its preservation.
\end{abstract}

KEYWORDS: Interpretive Trail; Rio+20; Non-Formal Education.

\section{RESUMO}

A educação ambiental contém em seu leque de possibilidades 0 aprendizado através da aproximação do ambiente natural com o cotidiano. Nesse contexto, caso estabelecida uma relação afetiva, a educação ambiental se torna mais do que meramente informativa. Ela pode contribuir com mudanças de comportamento, postura e visão crítica. Essa "forma de educação" pode ser realizada em ambientes naturais, através de visitas guiadas, trilhas interpretativas, placas de sinalização, entre outros. Em quaisquer das opções, é importante tornar atrativa a experiência de apreciação e, pelo menos em alguma medida, relevante para o "visitante", contribuindo desta forma para a internalização da necessidade de conservação, bem como para a divulgação da mesma.

PALAVRAS-CHAVE: Trilhas Interpretativas; Rio+20; Educação Não Formal. 


\section{Introduction}

Environmental Education (EE) has as its goal the process of teaching and learning values and attitudes toward environmental preservation (BRASIL, 1999). The base for this understanding is to be critic and creative while seeking society transformation (GUIMARÃES, 2004). In Brazil, Environmental Education is recognized by law (BRASIL, 1999), which states that it must be present in all levels and modalities of formal education and also in non-formal education. Regarding its role, the law determines that this education focus in building values concerning environmental conservation (BRASIL, 1999). In Brazil, EE is acknowledged as an interdisciplinary field, not as a single discipline (OTERO; NEIMAN, 2015). In this way, the proposal to recognize and deal with environmental issues is fully achieved (DI TULLIO 2005; HINTZE, 2009). EE may be considered an important path to reach sustainability, ensuring the quality of life (FREITAS; ZAÚ, 2015).

Considering the differences between non-formal and formal education, it is evident that learning environments in which non-formal education occurs usually allow more flexible activities than schools and classrooms (MARANDINO et al., 2003). As Environmental education aims to reestablish the meaning of nature it requires non-formal ways of teaching. That way, natural sites are good options to develop didactic activities (HINTZE, 2009).

There are over 320 Conservation Units (CU) in Brazil covering over 185 million acres of rich and protected biodiversity (ICMBio, 2015). Most of them can be usual as educational sites. For example, during guided walks it's possible to explore the concept of "knowing to preserve" that can be used to enlarge the visitor's knowledge about nature and the necessity of preserving it (MINISTÉRIO DA EDUCAÇÃO, 2006). There are some categories of CU that allow neither the direct use of their resources nor the presence of nonauthorized people. However, there are other categories in which public visitation is open and encouraged (BRASIL, 2000). Nevertheless, this kind of activity in addiction to considerable sized groups may be in some level harmful to the visited sites. A great number of people may apply significant impact over the soil, vegetation, wildlife and also landscape (e.g. HINTZE, 2009; ZAÚ, 2014). Over this background ecotourism emerges as a section within tourism that seeks to minimize environmental and social impacts due the tourism activities (HINTZE, 2009; WALTER, 2013; SOUZA, 2014).

To develop didactic activities in ecotourism it is important that those are well planned, for that the most reported strategy is the interpretative trails (DI TULLIO, 2005). Such activities bring more outcomes then a meaningless walk (DI TULLIO, op. cit.; SOUZA, 2014), especially when you aim critical thinking about the environment (SOUZA, 2014, PEDRINI, 2010). In other to accomplish that it's important that the group is prepared to deal with personal aspects of the visit, and is presented with questions and impressions concerning their attitude toward nature (FIGUEIREDO, 2012).

In order to comprehend the potential interactions between Environmental education and Ecotourism, this paper raises viewpoints that validate the use of ecotourism activities as also didactic activities. This issue has become significant as a result of the increase of tourism in natural sites 
(e.g. NETO, 2003) and for its potential for non-formal education not yet fully realized. We understand that it's important to clarify the purpose and extension of EE, aiming to reach not only visitors but also expand the theoretical repertoire of those responsible for disseminate scientific information, specially tour guides and UC's managers.

In this paper, we present a theoretical plan and data generation about the two core subjects, Ecotourism and Environmental education, considering their similar concepts. Furthermore, we discuss the results of the research on numbers of papers that have been published and are available online since Rio de Janeiro Earth Summit until now.

\section{A brief view on Environmental Education}

Environmental Education is the historical term for didactic practices related to nature issues (GUIMARÃES, 2004). It's the way an individual and a community build their social values toward environmental conservation (BRASIL, 1999). In Brazil, EE is known as an important path for sustainability and better quality of live (FREITAS; ZAÚ, 2015). EE aims to contribute to the solution of local problems through interdisciplinary and community participation (OTERO; NEIMAN, 2015). It is also a way to discuss political and social acts against environmental world problems (OTERO; NEIMAN op. cit), such as global warming and species lost. There is a great amount of designations referring to how it is performed didactically: education "for", "about" and "in" the environment (e.g. SATO, 1997); critical and transformative (e.g. LAYRARGUES, 2012), ecopedagogy (e.g. AVANZI, 2004), ecological literacy (e.g. MUNHOZ, 2004), formal and non-formal (MARANDINO et al., 2003), and so on.

In several approaches, EE puts the environment as a background for learning, where nature is presented in day-to-day basis (e.g. FREITAS; ZAÚ, 2015). Thought this premise it is possible to develop important values (DI TULLIO, 2005; DIAZ-ROCHA, 2007) to reestablish the relationship among man and nature (SOUZA, 2014; GUIMARÃES, 2004) individually and as a part of a community. "Work didactically the reason (cognitive) and the emotions (noncognitive) is essential to motivate the apprentice, but they are not enough to induce them to change their habits" (GUIMARÂES, op.cit. p. 31 , our translation).

As mentioned above, in Brazil Environmental Education must be present in formal and non-formal education. Some authors mention school's limits to teach society all it takes to understand reality (e.g. GUIMARÃES; VASCONCELLOS, 2006). One of these limitations is the massive tasks and lectures that institutions and teachers must accomplish during the year. On the other hand, non-formal education allows time and space flexibility (GOUVÊA et al., 2001) and it is important to science dissemination. Furthermore, non-formal sites are free to select and organize subject matters and their methodologies, fomenting interdisciplinarity.

Museums and science centers are the most popular places for nonformal education (MARANDINO et al., 2003). Thus, it's important to create 
playful activities and through them introduce visitors to an educational environment where the learning flows spontaneously (FIGUEIREDO, 2011; GUIMARÃES; VASCONCELLOS, 2006). This thought may also to be used by an environmental trend (FREITAS; ZAÚ, 2015): EE's interdisciplinarity provides social tools to create learning environments. These conceptions free learning and educational learning environments - are enough to consider natural places, such as National Parks, with high potential for education and science dissemination.

\section{Ecotourism in Brazil}

Brazil holds the biggest biodiversity in the world: over 46 thousand flora species, 108 thousand invertebrates and 8 thousand vertebrate species. From these, almost 4\% are listed as threatened (MMA, 2015; CNCFLORA, 2015). The most effective tool to manage this inheritance are the Conservation Units (CU). In the National System of Units of Conservation (SNUC in portuguese) these CU are split in two great groups: Full Protection, that aims conservation, and Sustainable Use, that allows population to directly benefit from that territory (BRASIL, 2000).

Regardless of all conservation strategy, the urban society development, specially the dominants economic systems, leads to changes and threats to the environment and its functionality. Among these threats to nature, forest fragmentation is the one that disturbs the most (LAURANCE et al., 2011). Tijuca National Park can be used to illustrate this issue considering it's is the most visited Park in the country, with over 3 million visitors per year (PARNA TIJUCA, 2016). Although it's the smallest park in size, it is in the city of Rio de Janeiro and holds places as the Christ Redeemer statue, what makes it core for national and international tourism (ZAÚ, 2014). All this attention requires special care to balance urban growth and nature needs so that both may survive side-to-side.

Tourism is an economic sector that is growing across the world (UNWTO, 2017). This kind of pastime for numerous and frequent groups can be negative for conservation of the visited area be.

cause soil, vegetation, minerals, water, wildlife an even landscape may be directly disturbed (HINTZE, 2009; ZAÚ, 2014). However, ecotourism is becoming an alternative and an additional form of tourism with the potential to minimize local environmental and social impacts (PEDRINI, 2005; ARABATZIS, GRIGOROUDIS, 2010), besides, it creates new job opportunities, income and sustainable businesses (MMA, 2015).

There are three characteristics that place a touristic activity as ecotourism: sustainability (environmental, social, cultural and economic); education aspects; and local community commitment. Among these three characteristics, using Environmental education to diffuse social and environmental consciousness is a great way to emphasize and distinguish the educational feature (WALTER, 2013). When confronted with nonpolitical views Critical EE sees ecotourism as an environmental purchase and misappropriation of traditional community land by corporations 
(LAYRARGUES, 2004). The same author emphasizes that it must be considered wisely to whom ecotourism's income is designated

Regarding travel packages, Hintze (2009) notices that touristic companies do not announce educational activities when purchasing them, claiming that such actions don't match with recreation moments. The marketplace relates education to only formal education - the one planned for schools and professional qualifications (MARANDINO et al., 2003) - and that may be a reason why educational work is avoided. This point of view sees learning as something not fun!

Dealing with ecotourism's basics characteristics - natural environment, education and sustainability - Walter (2013) specifies three varieties of ecotourism: wildlife, adventure, and community based. Their greatest differences are established by the size of groups, vacation planning activities, environmental commitment, destiny, accommodation and place facilities, local culture relation, and others (HINTZE, 2009; WALTER, 2013; SOUZA, 2014). Despite the differences, the three categories have similar elements that make then overlap (Figure 1). The characteristic that unites all: "Natural Attraction" as first appeal.

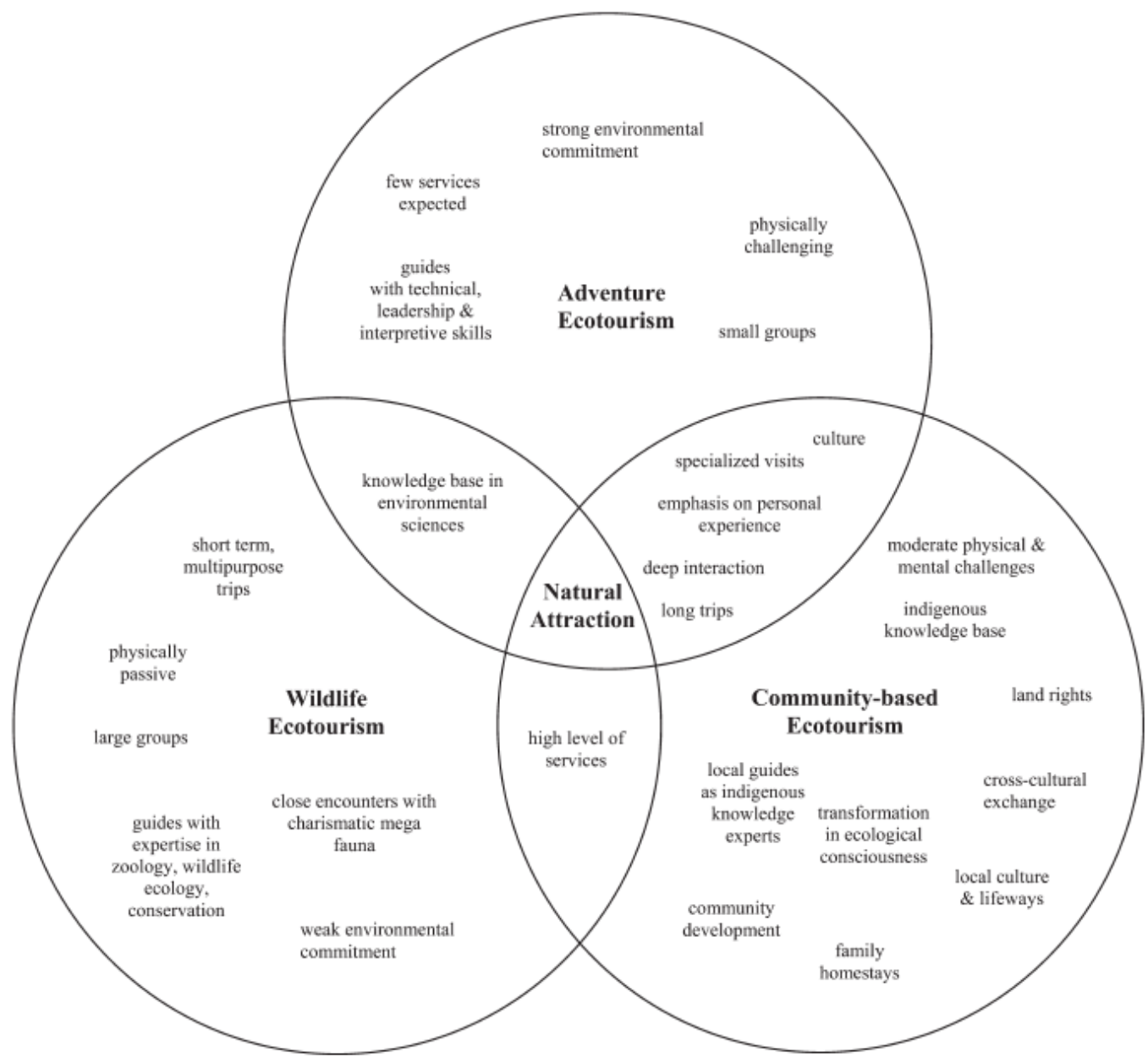

Figure 1: Comparing wildlife, adventure and community based ecotourism (WALTER, 2013 p. 18) Figura 1: Comparação entre ecoturismo de vida selvagem, de aventura e de base comunitária (WALTER, 2013 p.18) 
As Environmental Education is one of ecotourism's pillars, but knowing it's negative impacts caused by visitors, it's up to CU's administration to design appropriate places for visitation and their carrying capacities This planning aims to offer landscape observation, recreation areas for different ages, build information and educational centers, delimit trails for hiking, among others necessities. Furthermore, visitation must be interrupted or even prohibited in places with great significance for survival and/or breeding of flora and fauna species as well as places with threatened or endemic ones (ZAÚ, 2014; ZAÚ, FREITAS; ODA, 2015).

\section{Studies concerning environmental education and ecotourism}

In the 1990's numerous critical movements about the social and environmental crises came to light after the Stockholm Conference (LAGO, 2006) and especially due to the book "Silent Spring" (CARSON, 1972). It was in this atmosphere that the Rio de Janeiro Earth Summit took place in Brazil. It was considered a symbol for environmental and sustainable development discussions and thereafter for environmental education (OTERO; NEIMAN, 2015). Twenty years later, the Rio+20 Conference took place in a less influential atmosphere and the deals were less palpable in practice (OTERO; NEIMAN, op. cit.).

In this paper, we have performed data collection from Scopus ${ }^{\circledR}$ and Scholar Google ${ }^{\circledR}$. The key-words were: "ecotourism", "environmental education" and "Brazil". The timeframe was from the Rio de Janeiro Earth Summit conference (1992) until the present days (2016), totalizing 25 years. The arguments were defined according to limitations in each base (Table 1). Our aim was to quantify papers that have been published about these subjects.

Table 1: Specific arguments for each database. (*) Brazil was not one of the key-words in Google Scholar because these papers are in this country native language. Scopus $\AA^{\circledR}$ and Google Scholar®. 2016.

Tabela 1: Filtros específicos para cada base de dados. $\left({ }^{*}\right)$ Brasil não foi uma palavra-chave para a busca no Google Scholar porque a língua da pesquisa é a oficial deste país. Scopus $\AA$ and Google Scholar $\AA^{2} 2016$.

\begin{tabular}{|l|l|l|}
\hline & Scopus & Google Scholar \\
\hline \multirow{2}{*}{ Document type } & All documents & $\begin{array}{l}\text { All documents exept citation } \\
\text { and patent }\end{array}$ \\
\hline \multirow{2}{*}{ Search fields } & $\begin{array}{l}\text { Title: } \\
\text { education" + ecotourism }\end{array}$ & $\begin{array}{l}\text { Title: } \\
\text { education" + ecotourism }\end{array}$ \\
\cline { 2 - 3 } & All fields: Brazil & * \\
\hline Language & English & Portuguese (Brazil) \\
\hline
\end{tabular}


There have been raised 1.351 documents for "ecotourism" in Scopus ${ }^{\circledR}$, of which 9 included environmental education in its titles. For only "EE", 1.530 papers have been found. The combination of the three terms has resulted in only one document in all 25 years (Figure 2), showing a poor number of papers published in or about Brazil. Meantime it is noticeable an increase in order of magnitude from 1992 to 2016.

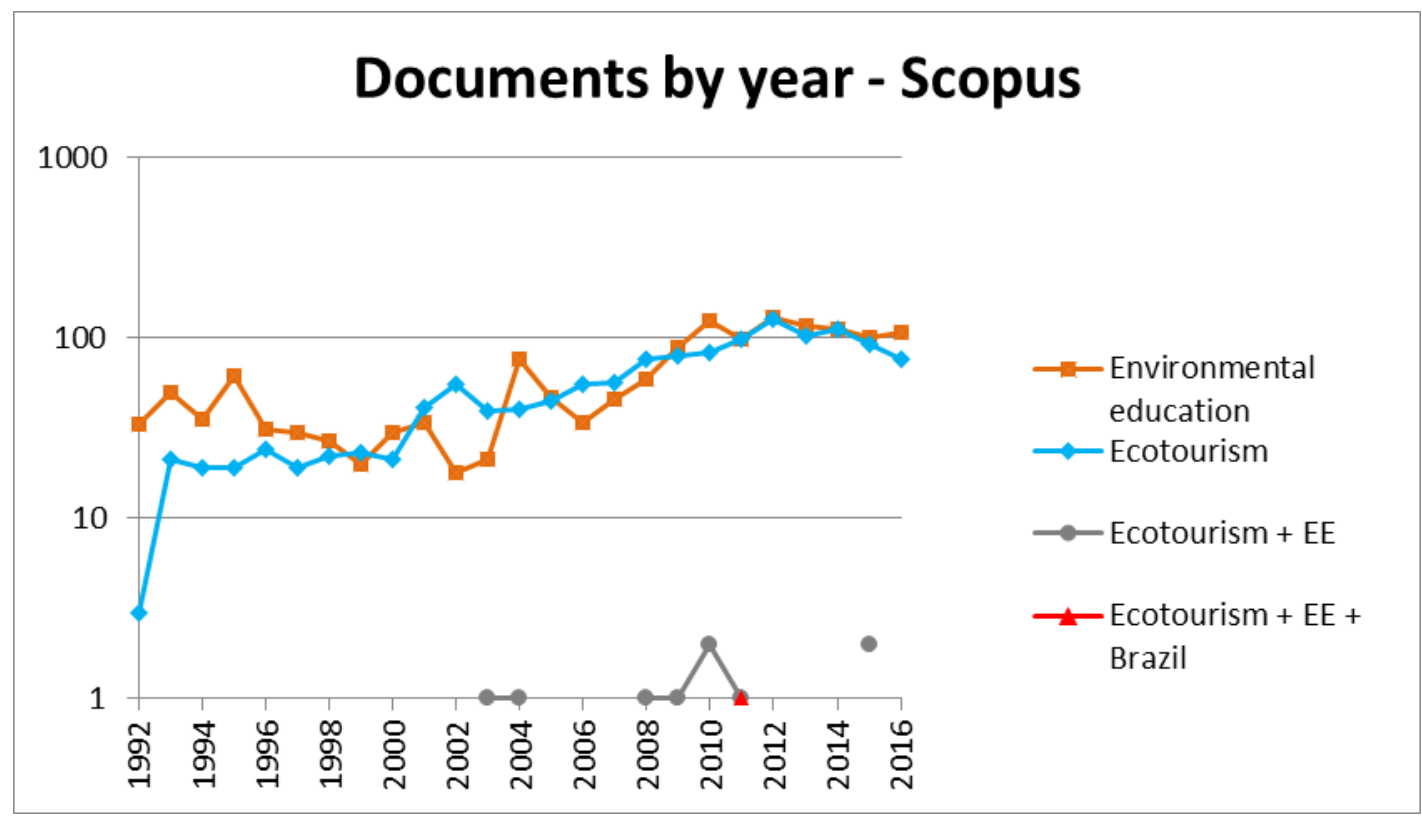

Figure 1: Logarithmic scale for the number of papers that display the words "Ecotourism", "Environmental education" and "Brazil" individually and in combination through the years. Scopus®. 2016.

Figura 2: Escala logarítmica para o número de publicações que apresentam "Ecotourism", "Environmental education" e "Brazil" separadamente ou em conjunto, ao longo dos anos. Scopus®. 2016.

However, when searching for the same terms in Portuguese through Scholar Google ${ }^{\circledR}$, the results showed around 500 links for "Ecotourism"; over 7800 for "EE" and only 51 for both in combination (Figure 3).

Until the beginning of the $21^{\text {st }}$ century there was no evident increasing in links for "EE" or "Ecotourism". Yet, from that time on the number of papers in "Environmental Education" increased by order of magnitude - from about 100 to almost 1.000, since 2000. Otherwise, ecotourism's raising was from less than 10 to almost 1.000 . The number of articles with both terms has not risen as it was expected in any of the database analyzed.

Surprisingly, the data for "EE + Ecotourism" and "Environmental education" in Portuguese was greater than in English. This shows that Brazil is producing a great number of scientific papers but their access is limited by the language for international scientific community. 


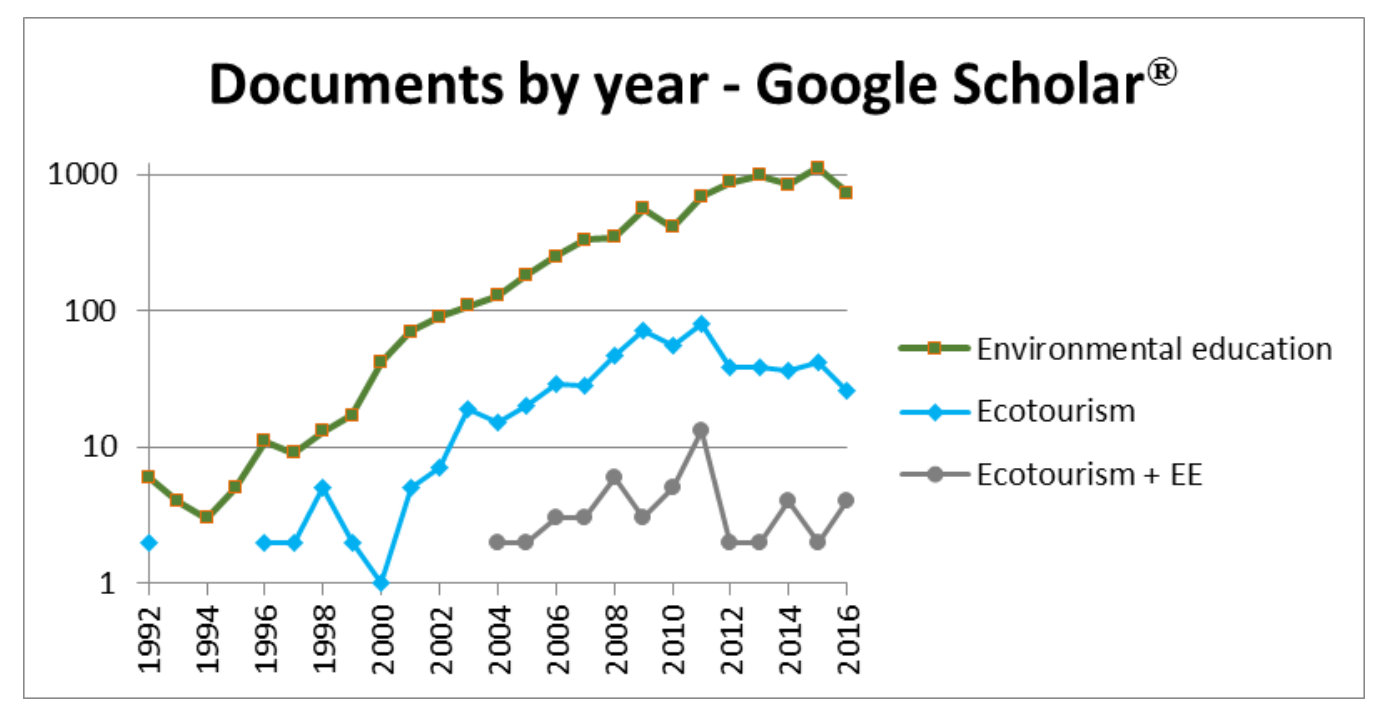

Figure 2: Logarithmic scale for the number of papers that display the words "Ecotourism" and "Environmental education" in portuguese individually and in combination through the years. Google Scholar®. 2016.

Figura 3: Escala logarítmica para o número de publicações que apresentam "Ecotourism" e "Environmental education" em português separadamente ou em conjunto, ao longo dos anos. Google Scholar®. 2016.

A research through Scopus ${ }^{\circledR}$ showed that during the selected time frame, 39 countries published papers in this database using "Ecotourism" and "Environmental education" in their titles, key-words or abstracts. The ranking is led by United States with over 30 articles and Brazil is in the $5^{\text {th }}$ position with 11 articles (Figure 4). The group "others" contains 30 countries and represent almost the same amount of publishers as USA.

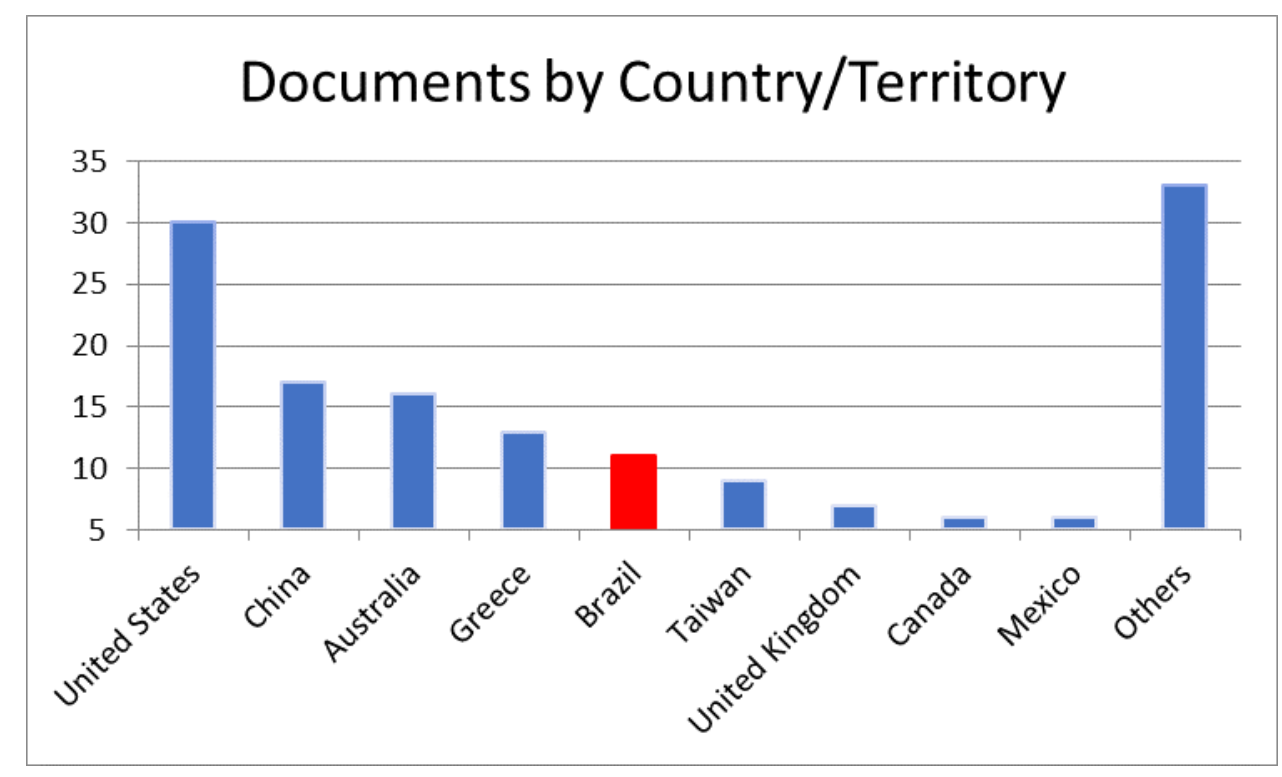

Figure 3: Number of papers by countries that contain the words "Ecotourism" and "Environmental education" in there titles, key-words or abstracts. Scopus®. 2016.

Figura 4: Número de publicações, por país, que apresentam "Ecotourism" e "Environmental education” em seus títulos, palavras-chave ou resumos. Scopus®. 2016 
In Brazil, these twenty years witnessed the creation of EE centers in different parts of the country that promote workshops and qualification courses (MMA, 2016). An example is REBEA (Brazilian Network of Environmental Education) created in 1992 to bring people and organizations in all over the country together to EE discussion (REBEA, 2004). In 2004, REBEA fomented the $V$ Environmental Education Forum, with over 4 thousand participants. With an extensive official program and numerous spontaneous performances (PORTILHO et al., 2010), this meeting showed the academic community sympathy toward the main subject and opened new research lines. In 2012, with the approval of the new Curriculum Guidelines for Environmental Education, educators started to acknowledge EE in the learning process and understand its importance not only for specialist or researchers (e.g. OTERO; NEIMAN, 2015), nor biologists (e.g. FREITAS; ZAÚ, 2015) but also to local community's realities and scientific dissemination.

\section{Ecotourism as a didactic activity}

It is necessary to examine today's complex world under new lens. These lenses are full with new paradigms as those Morin (2000) called "Seven knowledge topics to future's education". The first states that we must comprehend that the "mistake" is a part of knowledge and learning. Without mistakes we are not able to neither see nor understand the "right". Considering that, in a complex world knowledge is unified, it is up to science and education to understand it in this way. This encounters the overestimated paradigm of specialization which separate knowledge in smaller parts (MORIN, 2000). Through that we lose understand of totality.

Human kind has risen substantially from this knowledge fragmentation. In fact, solution given by specialists tends to be effective to solve specific problems. However, in the last decades these solutions are not enough for all the complex questions that has been raised. We must confront and expose our uncertainties. Science is build over uncertainties and this is it's foundation to face reality. The whole scientific process is about raising questions and hypothesis to be tested in each new experiment. These discovers and this new knowledge are what we believe until it it's proven otherwise. This is how science progresses. Nevertheless, it is important to be cautious with this kind of affirmative (GOLDIM, 2002). For example, if the current knowledge is not enough to precisely evaluate an environmental consequence due a human action, we must enlarge these researches before actually do it. Education must be understood in the same way: uncertainties and mistakes are part of learning.

People are forge by their culture, their believes, and their natural, physical, mental or imaginary conditions (MORIN, 2000). Understand these conditions and their complexity is essential to develop educational activities with different social groups. Furthermore it must be considered theses groups anachronism and cultural syncretism in a globalize world.

Considering Earth as the only planet that can host species we find here it is fully necessary to protect it. Its sustainability is essential to our life 
(MORIN, 2000). Programs, projects and policies that seek to improve life quality, ecological, social and economic sustainability - as ecotourism and environmental education - may be essential to maintain this planet.

In this anachronistic world we must teach and promote the understanding in a way to turn it in a basic element for communication (MORIN, 2000). Still, we live in a world where misunderstands are frequent in several aspects such as environmental, politic, social or religious (senso MORIN, op. cit.). Education is crucial to instruct citizens to dialogue and these dialogues are what society needs to become more comprehensive.

Also, through the eyes of Morin (2000), we must hail the ethic that is based on the individual, the society and the human kind. When the society is more humanistic, social policies are not imposed by anyone - majority, minorities, politics nor academics. Enlarge the dialogue between who create educational projects and the one's that apply it is becoming essential for our society's future.

In Brazil, a technique to develop learning in natural sites is the interpretative trail, which is considered effective ways to teach biology and natural sciences besides promoting a wide view of the environment (DI TULLIO, 2005). These trails are didactic strategies that go beyond traditional learning, and seek to develop emotional connections between humans and nature in a way to transform the visitor in a "discoverer" of the natural environment (DI TULLIO, op. cit.; PEDRINI, 2006). "The education, the perception and the playfulness must be used to expand a conservationist consciousness always through peoples' emotional attachment with nature and local cultures in a way to understand this new territory as their own" (NEIMAN; RABINOVICI, 2008 p. 97-98, our translation).

Interpretative trails fulfill this task because they behave as more than just a way or a meaningless walk (DI TULLIO, 2005; SOUZA, 2014). The way is important to unmask the untouchable nature (NEIMAN; RABINOVICI, 2008) that along with critical thoughts about environmental issues can raise people's awareness more effectively (SOUZA, op. cit.). Pedrini (2010) questions if a short path is enough to create new habits and behaviors, what brings a discussion on EE's quality. This is a primal question but it does not put aside the importance of inspiring a natural site and creating a relation with it through an educational process. For Neiman et al. (2009), it is important for the public to have environmental and cultural aspects decoded through professionals, pamphlets or advisers. Thinking over this discussion the Field Guide for Tijuca National park has been created to help teachers conduct a non-formal class in the Students Trail (UERJ, 2013). This guide contains several topics to be worked with elementary or high school students. It is important that teachers stay with the students during the visit. They will be responsible for keeping the students connected to the place (GUIMARÃES; VASCONCELLOS, 2006). According to these ideas, Falk (2006) says that the learning doesn't come from only one episode, but works as a cumulative process: what the visitor learns is determined first and mostly for his knowledge and interest before the visitation itself. Therefore, it is 
important to understand how the experience may increase the person's (in) formation, not evaluate its immediate results.

Tour guides and teachers are crucial to start and sustain the dialog and to share values, behaviors and attitudes among people (WALTER, 2013). In a study taken by Di Tullio (2005), middle school students were taken to an interpretative trail aiming to talk about conservation and biodiversity: "(...) what was most clear during the activity (...) was their perception toward the experience in contact with the natural environment and mostly in their interaction with their colleges and tour guides" (p. 124, our translation). This result shows the importance of dialogs and groups in EE. That was also noticed by Neiman and Rabinovici (2008). They performed a study in Alto do Ribeira State Park in Sao Paulo, Brazil, where visitors were leaded by some tour guides. In the end of the trail, when questioned about the highlights of the experience, several answers were similar and positive toward "wildlife nature", the "satisfaction of winning challenges in the cave", "the possibility to think about their life and feelings" (p. 85-86, our translation) and the friendship. Meantime, it is important to underline that each place and public require a different approach from the tour guides (WALTER, 2013).

Environmental education activities must be based on interdisciplinarity (e.g. MORIN, 2000; FREITAS; ZAÚ, 2015) to reach all section of someone's life (e.g. MORIN, op. cit.; DIAZ-ROCHA, 2007; FIGUEIREDO, 2012). They may present, for example, some principles from the Earth Charter that is an international declaration for ethical framework to build a just, sustainable and peaceful society in the XXI century (FIGUEIREDO, 2012). Beginning with these principles it is possible to arrange strategies for $E E$ in several activities. The respect for local communities; sustainability (MORIN, op. cit.); providences toward environmental conservation; the acknowledgement of humans as part of the environment and the respect within life forms can be easily worked with the public.

Projects developed in natural sites encourage people to change behaviors and this is "the key to the true environmental (re)education" (NEIMAN; RABINOVICI, 2008 p. 98, our translation). In this sense, natural spaces should be used for sensitization and learning, not just as tourist or recreational destinations.

\section{Conclusion}

One way to develop Environmental education is through projects in natural places. Understand how this process can influence behavior and changes social realities is still to be answered. That's probably the reason why in the last decade the number of national and mostly international papers about EE and Ecotourism has risen.

We believe that it is important to support EE's activities in natural sites and to include them in ecotouristic activities, turning these sites more than just places or touristic destinations. 


\section{References}

ARABATZTIS, G.; GRIGOROUDIS, E. Visitors's satisfaction, perception and gap analysis: The case of Dadia-Lefkimi-Souflion National Park. Forest Policy and Economics, vol. 12, n. 3, p.163-172, 2010.

AVANZI, M.R. Ecopedagogia. In: Ministério do Meio Ambiente. Identidades da educação ambiental brasileira. Brasília: Ministério do Meio Ambiente, p. 35-49, 2004.

BRASIL. Lei o 9.795 de 27 de abril de 1999. Dispões sobre proposta de diretrizes curriculares nacionais para a Educação Ambiental. Available at: $<$ http://www.planalto.gov.br/ccivil 03/leis/L9795.htm>. Accessed on: April 03, 2017

BRASIL. Lei. N ${ }^{\circ}$ 9.985, de 18 de julho de 2000. Dispõe sobre o Sistema Nacional de Unidades de Conservação da Natureza. Available at: $<$ http://www.planalto.gov.br/ccivil 03/leis/L9985.htm>. Accessed on: April 03, 2017.

CARSON, R. Silent Spring. Estados Unidos: Ed. Houghton Mifflin, 1962.

CENTRO NACIONAL DE CONSERVAÇÃO DA FLORA (CNCFlora). Available at: <http://cncflora.jbri.gov.br/portal/>. Accessed on: July 17, 2015.

DI TULLIO, A. A abordagem participativa na construção de uma trilha interpretativa como uma estratégia de educação ambiental em São José do Rio Pardo SP. 2005. Tese (Mestrado em Ciências da Engenharia Ambiental) - Escola de Engenharia de São Carlos - Universidade de São Paulo, São Paulo. 2005.

DIAZ-ROCHA, P.E. Aplicação do Lúdico na Educação Ambiental. In: PEDRINI, A. G. (Org.). Metodologias em Educação Ambiental. Rio de Janeiro: Vozes, p. 95-125, 2007.

FALK, J.H. Free-choice environmental learning: framing the discussion. Environmental Education Research, vol. 11, n. 3, p. 265-280, 2006.

FIGUEIREDO, J.P. Atitudes de condutores de atividades de aventura e a perspectiva de disseminação da sensibilização ambiental. 2012. Tese (Mestrado em Ciências da Motricidade) - Instituto de Biociências Universidade Estadual Paulista, Rio Claro, São Paulo. 2012.

FIGUEIREDO, J.P. et al.. Lazer e educação ambiental: a estratégia dos jogos e brincadeiras. Anais do $23^{\circ}$ encontro nacional de recreação e lazer. Várzea Paulista, São Paulo, 2011.

FREITAS, J.R.S.; ZAÚ, A.S. Educação ambiental a partir da interação entre a sala de aula e arredores da comunidade. Revista Brasileira de Educação Ambiental, São Paulo, vol. 10, n. 2, p. 249-269, 2015.

GOLDIM, J. R. O princípio da precaução. 2002. Available at: $<$ http://www.bioetica.ufrgs.br/precau.htm> Accessed on: April 11, 2017.

GOOGLE Scholar. Available at: <https://scholar.google.com.br/> Accessed on January 17, 2017 
GOUVÊA, G. et al.. Redes Cotidianas de Conhecimento e os Museus de Ciência. Parcerias Estratégicas vol. 6, n.11, p. 169-174, 2001.

GUIMARÃES, M. Educação ambiental crítica. In: Ministério do Meio Ambiente. Identidades da educação ambiental brasileira. Brasília: Ministério do Meio Ambiente, p. 25-34, 2004.

GUIMARÃES, M.; VASCONCELLOS, M.M.N. Relações entre educação ambiental e educação em ciências na complementaridade dos espaços formais e não formais de educação. Educar. Curitiba, Ed. UFPR, n. 27, p. 147-162, 2006.

HINTZE, H.C. Ecoturismo na cultura de consumo: possibilidade de Educação Ambiental ou espetáculo? Revista Brasileira de Ecoturismo, São Paulo, v.2, n.1, p.57-100, 2009.

INSTITUTO Chico Mendes da Conservação da Biodiversidade - ICMBIO. Disponível em: <http://www.icmbio.gov.br/portal/unidades-de-conservacao >. Acesso em: 20 jul. 2015.

LAGO, A.A.C. Estocolmo, Rio, Johanesburgo: o Brasil e as três conferências ambientais das nações unidas. Brasília: Thesaurus Editora, 2006

LAURANCE, W.F. et al.. The fate of Amazonian forest fragments: A 32-year investigation - Biological Conservation, vol. 144, p. 56-67, 2011.

LAYRARGUES, P.P. A função social do ecoturismo. SENAC, 2004. Available at: $<$ http://www.educacaoambiental.pro.br/victor/biblioteca/LayrarguesEcoTuris mo.pdf > Accessed on: April 03, 2017.

LAYRARGUES, P.P. Educação para gestão ambiental: a cidadania no enfrentamento político dos conflitos socioambientais. In: CASTRO, R.S. (Org.). Sociedade e Meio Ambiente: a Educação Ambiental em Debate. São Paulo, Cortez, p. 87-155 , 2012.

MARANDINO, M. et al. A educação não formal e a divulgação científica: $O$ que pensa quem faz? Ata do IV Encontro Nacional de Pesquisa em Educação em Ciências. Bauru, São Paulo, 2003.

MINISTÉRIO DA EDUCAÇÃO. Guia de Educação Ambiental: conhecer e preservar as florestas. Coleção Educação para a Cidadania, Portugal, 2006. Available at: <http://www.icnf.pt/portal/agir/resource/doc/sab-ma/florest/guiaflorestas> Accessed on: April 03, 2017

MINISTÉRIO DO MEIO AMBIENTE (MMA). Available at: <http://www.mma.gov.br/mma-em-numeros >. Accessed on: July 17, 2015.

MINISTÉRIO DO MEIO AMBIENTE (MMA). Available at: $<$ http://www.mma.gov.br/educacao-ambiental/politica-de-educacao-

ambiental/historico-brasileiro> Accessed on: July 12, 2016

MORIN, E. Os sete saberes necessários à educação do futuro, 2000. Available at: <http://bioetica.catedraunesco.unb.br/wpcontent/uploads/2016/04/Edgar-Morin.-Sete-Saberes.pdf> Accessed on: April 11, 2017 
MUNHOZ, D. Alfabetização Ecológica de Indivíduos às Empresas do Século XXI. In: MINISTÉRIO DO MEIO AMBIENTE (org.). Identidades da Educação Ambiental Brasileira. Brasília, p. 141-155, 2004.

NEIMAN, Z.; CARDOSO-LEITE, E.; PODADERA, D.S. Planejamento e implantação participativos de programa de interpretação em trilhas na "RPPN Paiol Maria", Vale do Ribeira (SP). Revista Brasileira de Ecoturismo, vol. 2, n.1, p.11-34, 2009.

NEIMAN, Z.; RABINOVICI, A. A Educação Ambiental através do Ecoturismo: o diferencial das atividades de contato dirigido com a natureza. Pesquisa em Educação Ambiental, vol. 3, n. 2, p. 77-10, 2008.

NETO, F. A new approach to sustainable tourism development: Moving beyond environmental protection, 2003. Available at: $<$ http://www.un.org/esa/esa03dp29.pdf>. Accessed on: August 24, 2016.

OTERO, P.B.G.; NEIMAN, Z. Avanços e desafios da educação ambiental brasileira entre a rio92 e a rio+20. Revista Brasileira de Educação ambiental, vol. 10, n. 1, p. 20-41, 2015.

PARQUE NACIONAL DA TIJUCA (PARNA Tijuca). Available at: $<$ http://www.parquedatijuca.com.br/\#parque $>$. Accessed on: April 03, 2017.

PEDRINI, A.G. Avaliação da educação ambiental no ecoturismo (em trilhas) no Brasil: uma proposta baseada na qualidade conceitual. OLAM Ciência \& Tecnologia. vol. 6, n. 2, 2006.

PEDRINI, A.G. Educação Ambiental pelo Ecoturismo numa trilha marinha no Parque Estadual da Ilha Anchieta, Ubatuba (SP). Revista Brasileira de Ecoturismo, vol. 3, n.3, p.428-459, 2010.

PEDRINI, A.G. Em busca da educação ambiental no (eco)turismo brasileiro; um ensaio. Anais do I Encontro Interdisciplinar de Ecoturismo em Unidades de Conservação. Rio de Janeiro, 2005.

PORTILHO, F. et. al. Consumo e Meio Ambiente: Como a Educação Ambiental Brasileira Aborda Essa Relação? Anais do V Encontro Nacional da Anppas. Florianópolis, SC, 2010.

REDE Brasileira de Educação Ambiental - REBEA. V Fórum Brasileiro de Educação Ambiental. Revista brasileira de educação ambiental, vol. 1, 2004.

SATO, M. Educação para o Ambiente Amazônico. 1997. Tese (Doutorado em Ecologia e Recursos Naturais) - Centro de Ciências Biológicas e da Saúde- Universidade Federal de São Carlos, São Paulo, 1997.

SCOPUS. Available at: <https://www.scopus.com/home.uri>. Accessed on: January 17, 2017

SOUZA, M.C.C. Educação ambiental e as trilhas: contexto para a sensibilização ambiental. Revista brasileira de educação ambiental, vol. 9, n 2: p. 239-253, 2014. 
UNIVERSIDADE do Estado do Rio de Janeiro - UERJ. Guia do Parque Nacional da Tijuca estimula a consciência socioambiental de alunos da rede pública. UERJemdia, Rio de Janeiro, 11 a 17 de novembro de 2013. Available at: <http://www.ueri.br/publicacoes/uerj emdia/663/>. Accessed on: July 18, 2013.

WORLD TOURISM ORGANIZATION - UNWTO. Available at: <http://www2.unwto.org/en> Accessed on: April 11, 2017.

WALTER, P.G. Theorizing visitor learning in ecotourism. Journal of Ecotourism, vol. 12, n. 1, p. 15-32, 2013. Available at: $<$ http://dx.doi.org/10.1080/14724049.2012.742093>. Accessed on: may 20, 2015.

ZAÚ, A.S. A conservação de áreas naturais e o Ecoturismo. Revista Brasileira de Ecoturismo, vol.7, n.2, p.290-32, 2014.

ZAÚ, A.S.; FREITAS, G.P; ODA, G.A.M. Do visitors attract or repel vertebrates in a Brazilian Atlantic Florest National Park? Revista Brasileira de Ecoturismo, vol.8, n.5, p.543-555, 2016.

\section{Acknowledgments}

We thank Daniel Fonseca de Andrade, Alexandre de Gusmão Pedrini and Aline Silva Machado for their comments to an early version of this manuscript. This study was partialy fund. The research is based on the graduation paper developed in UNIRIO by the first author. There are no conflicts of interest related to this research.

Thaís Varandas de Azeredo: Universidade Federal do Estado do Rio de Janeiro, Rio de Janeiro, RJ, Brasil.

E-mail: thaisvazeredo@gmail.com

Link para o currículo Lattes: http://lattes.cnpq.br/2770016247026105

André Scarambone Zaú: Universidade Federal do Estado do Rio de Janeiro, Rio de Janeiro, RJ, Brasil.

E-mail: andrezau@unirio.br

Link para o currículo Lattes: http://lattes.cnpq.br/9561885200662079

Data de submissão: 26 de Abril de 2017

Data de recebimento de correções: 31 de julho de 2017

Data do aceite: 31 de julho de 2017

Avaliado anonimamente 